\title{
Primary Biliary Cirrhosis-
}

\section{Related Autoimmune Hemolytic Anemia: Three Case Reports and Review of the Literature}

\author{
YuTian Chi Wang Jian-Xiang Liu Hua-Hong Wang \\ Department of Gastroenterology, Peking University First Hospital, Beijing, \\ PR China
}

\section{Key Words}

Primary biliary cirrhosis - Autoimmune hemolytic anemia - Drug therapy

\begin{abstract}
The association between primary biliary cirrhosis (PBC) and autoimmune hemolytic anemia (AIHA) is uncommon; only fourteen such case reports have been described. In this report, three patients who developed AIHA on the basis of PBC underwent successful therapy with corticosteroids and ursodeoxycholic acid (UDCA). Patient 3 was more complicated, suffering from PBC, Evans syndrome, Sjögren syndrome and Klinefelter syndrome simultaneously. This has not previously been reported in the world literature. Review of all fifteen cases showed that there is a prominent occurrence sequence that AlHA might take place on the basis of PBC. With sufficient doses of corticosteroids or immunosuppressant therapy, besides hemolysis under effective control, liver function also improved. According to the criteria of secondary AIHA, we may call them PBC-related AIHA. Thus, patients with PBC with serum bilirubin levels rising suddenly should undergo screening for associated hemolysis. Recommended treatment for PBC-related AIHA includes sufficient doses of corticosteroids to control the hemolysis in the acute phase, and immunosuppressant or adequate dose of UDCA to maintain therapy. These case reports have been increasing in recent years, so further reserch is needed to illustrate the incidence and natural courses of these two organ-specific autoimmune diseases.
\end{abstract}

\section{Introduction}

Although the etiology of primary biliary cirrhosis (PBC) is unclear, it is probably related to altered immunoregulation [1]. Autoimmune hemolytic anemia (AIHA) is characterized by a positive direct Coombs' test. It is idiopathic (primary) in 
approximately $50 \%$ cases or secondary to medication, hematological malignancies and autoimmune disorders [2].The association between PBC and other autoimmune diseases has been reported, mostly including rheumatoid arthritis, Sjögren syndrome, scleroderma, and so on [3]. However, the association between PBC and AIHA is uncommon. To our knowledge, only fourteen such case reports have been described in the world literature [4-17]. We now describe the cases of three such patients.

\section{Patient 1}

A 74-year-old woman was admitted to our hospital in December 2006, with a history of fatigue, anorexia and jaundice for about one month. Her past medical history included hypertension and hyperlipidemia diagnosed at ages 44 and 54 . She was a nondrinker but a smoker. On admission, physical examination revealed mild jaundice, conjunctival pallor and peripheral edema,

hepatosplenomegaly and ascites. Laboratory data revealed severe anemia: hemoglobin $(\mathrm{Hb}) 6.1 \mathrm{~g} / \mathrm{dl}$ (range 13.7-17.9 g/dl); white blood cell count (WBC) and blood platelet count (PLT) were normal. Reticulocyte (RET) was increased at $4.77 \%$ (range 1.0-2.5\%). Stool occult blood test was negative. Liver function test: ALT and AST were both in normal range; total serum bilirubin (T-bil) $47.5 \mathrm{mg} / \mathrm{l}$ (range 1$10 \mathrm{mg} / \mathrm{l}$ ); direct serum bilirubin (D-bil) $7.7 \mathrm{mg} / \mathrm{l}$ (range 1-4 mg/l); albumin $29 \mathrm{~g} / \mathrm{l}$ (range 35-50 g/l); alkaline phosphatase (ALP) $186 \mathrm{IU} / \mathrm{l}$ (range 40-160 IU/l); $\gamma$-glutamyltranspeptidase $(\gamma$-GT) $127 \mathrm{IU} / \mathrm{l}$ (range $0-50 \mathrm{IU} / \mathrm{l}$ ). Hepatitis B surface antigen and antibody to hepatitis $\mathrm{C}$ virus were both negative. Ultrasonography showed hepatosplenomegaly, ascites and multiple stones in the gallbladder. Coombs' test was performed and it was positive for anti-IgG. The bone marrow aspirate showed erythroid hyperplasia obviously with ripe erythrocytes polychromasia and inequality of size. Serum immunoglobulin M (IgM) 5.44 g/l (range 0.63-2.77 g/l); immunoglobulin G (IgG) $22.10 \mathrm{~g} / \mathrm{l}$ (range 7.23-16.85 g/l); immunoglobulin A (IgA) $3.41 \mathrm{~g} / \mathrm{l}$ (range 0.69-3.82 g/l); antinuclear antibody (ANA) 1:1000, antimitochondrial antibody (AMA) 1:1000, $\mathrm{M}_{2}$ subtype positive. On this basis $\mathrm{PBC}$ combined with AIHA was diagnosed.

Prednisolone (PSL) $60 \mathrm{mg}$ and ursodeoxycholic acid (UDCA) $750 \mathrm{mg}(12.5 \mathrm{mg} / \mathrm{kg})$ daily were given. At the same time, the patient was commenced on high dosages of intravenous immunoglobulin $(20 \mathrm{~g}$ daily) for 5 days, spironolactone $60 \mathrm{mg}$, furosemide $20 \mathrm{mg}$ and a daily 1 litre fluid restriction. This resulted in $3 \mathrm{~kg}$ weight loss with noticeable improvement in her ascites and peripheral edema. Her anemia responded to PSL quickly. Three weeks after initiation of therapy, her Hb level had recovered to $9.1 \mathrm{~g} / \mathrm{dl}$, RET to $1.84 \%$, and liver function had improved: albumin $35.1 \mathrm{~g} / \mathrm{l}$; ALP $53 \mathrm{IU} / \mathrm{l} ; \gamma$-GT $42 \mathrm{IU} / \mathrm{l}$. PSL was then gradually tapered and UDCA continued with the same dosage. Tow months later, her Hb had risen to $11.6 \mathrm{~g} / \mathrm{dl}$. During one-year follow-up her Hb was stable and PSL $10 \mathrm{mg}$ and UDCA $750 \mathrm{mg}$ daily were continued.

\section{Patient 2}

A 60-year-old man was admitted to our hospital in March 2007 with a 2-year history of progressive fatigue and anorexia. He had a small quantity of alcohol consumption (ethanol $<25$ g per week). On admission, physical examination revealed neither jaundice nor xanthelasma, but mild splenomegaly and conjunctival pallor. Laboratory data revealed the following: $\mathrm{Hb} 5.4 \mathrm{~g} / \mathrm{dl}$; RET 1.18\%; WBC and PLT were in normal range. ALT, AST, T-bil, D-bil were all normal. ALP 128 IU/l; $\gamma$-GT 110 IU/l. Hepatitis B surface antigen and antibody to hepatitis $C$ virus were both negative. Stool occult blood test was negative. Elevated level of IgM, $3.58 \mathrm{~g} / \mathrm{l}$ was noted, but IgG and IgA were normal. ANA and AMA were both positive at a titer of 1:1000, and $\mathrm{AMA} \mathrm{M}_{2}, \mathrm{M}_{4}$ subtype were both positive. Abdominal ultrasonography revealed mild splenomegaly. The bone marrow aspirate showed erythroid hyperplasia obviously with ripe erythrocytes polychromasia and inequality of size. Blood transfusion with packed red blood cell was instituted for cardiorespiratory distress relief. However, after transfusion his $\mathrm{Hb}$ descended to $5.1 \mathrm{~g} / \mathrm{dl}$ and RET to $6.39 \%$; Coombs' test was performed, and the outcome was positive for anti-IgG. He was diagnosed as PBC combined with AIHA.

The patient was treated with PSL $60 \mathrm{mg}$ and UDCA $750 \mathrm{mg}(12 \mathrm{mg} / \mathrm{kg})$ daily. His anemia responded to this treatment. Three weeks after initiation of therapy, his $\mathrm{Hb}$ level had recovered to $8.0 \mathrm{~g} / \mathrm{dl}$, RET to 2.36\%, and his liver function had improved: ALP $45 \mathrm{IU} / \mathrm{l} ; \gamma$-GT $63 \mathrm{IU} / \mathrm{l}$. After 3 months of this therapy his $\mathrm{Hb}$ had risen to $12.2 \mathrm{~g} / \mathrm{dl}$ with a normal liver function. During a one-year period, PSL was gradually tapered to $10 \mathrm{mg}$ per day and UDCA was continued. A year later, in April 2008, liver needle biopsy was 
performed; the outcome showed mild aggregates of lymphoid cells and fibrosis in the portal area, and the bile ducts were scanty. The lumens of the residual bile ducts were irregular. The pathologic findings were compatible with PBC.

\section{Patient 3}

A 55-year-old man was admitted to our hospital in May 2008, with a 4-month history of fatigue. His past medical history included: PBC, immune thrombocytopenia purpura (ITP), Sjögren syndrome and Klinefelter syndrome. In 2002 health examination had revealed that he had thrombocytopenia (PLT $\left.10 \times 10^{9} / \mathrm{l}\right)$ and splenomegaly. Platelet-associated $\operatorname{IgG}(\mathrm{PAIgG})$ and antiphospholipid antibody were strongly positive. Bone marrow examination revealed increased megakaryocytes without any other significant findings. Chromosome karyotyping analysis showed 47XXY. Liver biopsy was performed and the specimen showed moderate to generous aggregates of plasmacytes and lymphocytes with mild piecemeal necrosis and lobular disorganization. AMA and $\mathrm{M}_{2}$ subtype were both positive. Excessive dryness of mouth and eyes were other symptoms of this patient. Schirmer's test, saliva flow rate and biopsy of salivary gland were performed, and the outcomes were compatible with Sjögren syndrome. Thus, PBC, ITP, Sjögren syndrome and Klinefelter syndrome were diagnosed.

UDCA $(8.5 \mathrm{mg} / \mathrm{kg}$ ) was given combined with prednisone $40 \mathrm{mg}$ daily. After one month of therapy his PLT rose to $50-60 \times 10^{9} / 1$. Prednisone was intermittently used and thrombocytopenia was partially controlled. In February 2004, he had splenectomy. After the operation cyclophosphamide (CTX), azathioprine (AZA) or cyclosporine A (CsA) were successively used.

In January 2008, because of extremely fatigue he came to our hospital. On admission, physical examination revealed pallid conjunctiva, rampant caries and testicular maldevelopment. Laboratory data revealed: $\mathrm{Hb} 5.8 \mathrm{~g} / \mathrm{dl}$, PLT $5 \times 10^{9} / \mathrm{l}$, RET 3.6\%. Stool occult blood tests were negative two times. Liver function tests were normal. ANA 1:1000. PAIgG was positive; Coombs' test was positive for anti-IgG. PBC combined with Evans syndrome, Klinefelter syndrome and Sjögren syndrome were diagnosed. UDCA $600 \mathrm{mg}$ daily did not adjust, but PLS $60 \mathrm{mg}$ daily was added, and daily CsA $200 \mathrm{mg}$ intravenous injection was given for continuous three days. After three days, CsA $100 \mathrm{mg}$ daily was given orally. Three weeks after the treatment, the patient felt that fatigue was ameliorated obviously. $\mathrm{Hb}$ had risen to $8.6 \mathrm{~g} / \mathrm{dl}$, PLT to $20 \times 10^{9} / \mathrm{l}$, and RET to $2.06 \%$.

\section{Discussion}

$\mathrm{PBC}$ is a slowly progressive autoimmune disease. The diagnosis of $\mathrm{PBC}$ is based on three criteria: elevation of liver enzymes (most commonly ALP and $\gamma$-GT), presence of detectable AMA in the serum, and liver histologic findings that are compatible with the presence of the disease [18]. While AIHA is also an immune disease which is caused by antibodies directed against autologous red cells, the diagnosis is based on the presence of anemia, signs of hemolysis with reticulocytosis, increased lactate dehydrogenase, elevated indirect bilirubin, and a positive Coombs' test [2].

The association between PBC and AIHA is uncommon. Only fourteen such case reports have been described. All these fourteen cases reported previously with an association of PBC and AIHA are summarized in table 1 and table 2 . Because of language barrier, we could not obtain data from two of the reports, so 12 reports (15 patients) are summarized.

For those patients combining PBC with AIHA, it is puzzling that besides the liver, the immune attack focuses on red blood cells, where mitochondrial autoantigens are not found. Is the association a coincidence? Searching PubMed and using 'autoimmune hemolytic anemia' and 'liver cirrhosis', only 25 articles were found in last 30 years. Although PBC is not a common cause of liver cirrhosis, most of the articles are about PBC in combination with AIHA. Does this indicate that PBC patients have the pathophysiological foundations for AIHA occurrence? 
Another interesting thing is that none of the 18 patients suffered from AIHA before $\mathrm{PBC}$ was diagnosed. Although the two conditions were detected at the same time in some of the patients, not all patients with $\mathrm{PBC}$ received the diagnosis when it was at an early stage because of their asymptomatic status [19], and it is supposed that AIHA occurred after PBC development in these patients. The occurrence suggests a possible relationship between the two diseases. $\mathrm{PBC}$ patients are likely to have some conditions which can induce generation of anti-erythrocyte antibodies [8].

With sufficient corticosteroids or immunosuppressant therapy, hemolysis control in these PBC patients achieves a very good treatment effect (table 2). Hemolysis was controlled. In addition, liver function was improved in all of the 16 patients who had been successfully treated. Corticosteroid treatment is not only a preferred therapy for AIHA, but an adjuvant therapy that benefits $\mathrm{PBC}$ patients [20]. According to the criteria of secondary AIHA [2]: (1) AIHA would occur on the basis of PBC; (2) reversal of AIHA and liver function improvement of $\mathrm{PBC}$ happened simultaneously with the intake of immunosuppressive agents; (3) both $\mathrm{PBC}$ and AIHA are known to be immune-mediated diseases. Thus, we could call them PBC-related AIHA.

Serum bilirubin levels have long been known to be important in assessing the prognosis of $\mathrm{PBC}$, but confounding hemolysis may lead to erroneous conclusions about the severity of PBC. At the same time, compared with primary AIHA, this PBC-related AIHA is life-threatening but can be controlled. If no attention is paid to this condition, primary $\mathrm{PBC}$ will be ignored, as $50-60 \%$ of $\mathrm{PBC}$ patients are asymptomatic at diagnosis [21]. Therefore patients with PBC whose serum bilirubin levels rise suddenly should undergo screening for associated hemolysis.

The recommended treatment for PBC-related AIHA includes sufficient doses of corticosteroids to control the hemolysis at the acute phase, and immunosuppressant (for example CTX and CsA) or adequate dose of UDCA to maintain therapy. To deal with the severe, life-threatening hemolysis, intravenous immunoglobulin and large dosage of corticosteroids impact therapy may be considered. Only UDCA therapy for PBC patients with mild AIHA had a successful report [8], so in mild cases this method could be considered with regular blood cell counts to monitor response. Although Kaibori et al. [5] provided a successful case that could confirm liver transplantation and splenectomy is a curative therapy to PBC-related AIHA, as Retana et al. [6] reported, hemolysis also occurred after liver transplantation despite well-functioning graft. So immunosuppressant prescribed after liver transplantation and splenectomy would not avoid further production of anti-erythrocyte antibodies in all of the cases. Other immunosuppressants, for example rituximab (anti-CD20), appear to be highly effective in patient with warm antibody AIHA that is refractory to standard therapy. So it will become a potential treatment for PBC-related AIHA, which is refractory to the above treatment.

As illustrated in table 1, case reports have been growing in number in recent years. If our three case reports are added, in the last 8 years (since 2000) there have been 13 cases $(13 / 18)$ reported. Thus, further research is required for illustrating the incidence and natural courses of these two organ-specific autoimmune diseases. 
Table 1. Characteristics of PBC-related AIHA cases reported in the world literature

\begin{tabular}{|c|c|c|c|c|c|c|c|c|c|}
\hline Authors & Country & $\begin{array}{l}\text { No. of } \\
\text { patients }\end{array}$ & Sex & Race & $\begin{array}{l}\text { Onset age } \\
\text { PBC/AIHA }\end{array}$ & $\begin{array}{l}\text { Liver } \\
\text { pathology }\end{array}$ & Coombs' test & $\begin{array}{l}\text { AMA/ } \\
\text { ANA }\end{array}$ & $\begin{array}{l}\text { Nadir } \\
\mathrm{Hb}\end{array}$ \\
\hline $\begin{array}{l}\text { Azad et al., } 2007 \\
{[4]}\end{array}$ & Australia & 1 & $f$ & Australian & $81 / 83$ & * & $\begin{array}{l}+; \\
\text { warm-type }\end{array}$ & $+1-$ & $66 \mathrm{~g} / 1$ \\
\hline $\begin{array}{l}\text { Kaibori et al., } \\
2007 \text { [5] }\end{array}$ & Japan & 1 & $\mathrm{f}$ & Japanese & $38 / 49$ & PBC III & $\begin{array}{l}\mathrm{C}_{3}+\mathrm{IgM}+ \\
\text { cold-type }\end{array}$ & $+/-$ & $45 \mathrm{~g} / \mathrm{l}$ \\
\hline \multirow[t]{3}{*}{$\begin{array}{l}\text { Retana et al., } 2007 \\
\text { [6] }\end{array}$} & \multirow[t]{3}{*}{ USA } & \multirow[t]{3}{*}{3} & f & \multirow[t]{3}{*}{ American } & $43 / 62 / 65^{\Delta}$ & $* * *$ & $\begin{array}{l}\text { IgG+; } \\
\text { warm-type }\end{array}$ & $* / *$ & $23 \%^{* *}$ \\
\hline & & & $\mathrm{m}$ & & $49 / 54 / 59^{\Delta}$ & $* * *$ & $\begin{array}{l}\mathrm{C}_{3}+\mathrm{IgG}+; \\
\text { warm-type }\end{array}$ & $* / *$ & $24 \%^{* *}$ \\
\hline & & & $\mathrm{m}$ & & $43 / 47 / 59^{\Delta}$ & $* * *$ & +; warm-type & $* / *$ & $25 \% * *$ \\
\hline $\begin{array}{l}\text { Cantalapiedra et } \\
\text { al., } 2005 \text { [7] }\end{array}$ & Spain & 1 & $\mathrm{f}$ & Spanish & $50 / 50$ & PBC I/II & $\begin{array}{l}\mathrm{C}_{3}+\mathrm{IgG}+; \\
\text { warm-type }\end{array}$ & & $71 \mathrm{~g} / 1$ \\
\hline $\begin{array}{l}\text { Fuller et al., } 2003 \\
\text { [8] }\end{array}$ & Australia & 1 & $\mathrm{f}$ & Australian & $58 / 62$ & PBC III & $\begin{array}{l}\mathrm{C}_{3}+\mathrm{IgG}+; \\
\text { warm-type }\end{array}$ & $+l^{*}$ & $91 \mathrm{~g} / \mathrm{l}$ \\
\hline $\begin{array}{l}\text { Nakasone et al., } \\
2000 \text { [9] }\end{array}$ & Japan & 1 & $\mathrm{f}$ & Japanese & $68 / 68$ & PBC III & $\begin{array}{l}\mathrm{C}_{3}+\mathrm{IgG}+; \\
\text { warm-type }\end{array}$ & $-1+$ & $63 \mathrm{~g} / \mathrm{l}$ \\
\hline Brackstone and & Canada & 2 & $\mathrm{f}$ & Canadian & $49 / 58$ & PBC IV & cold-type & $+l^{*}$ & $82 \mathrm{~g} / 1$ \\
\hline Ghent, 2000 [10] & & & $\mathrm{f}$ & & $66 / 68$ & PBC III & warm-type & $+l^{*}$ & $58 \mathrm{~g} / \mathrm{l}$ \\
\hline $\begin{array}{l}\text { Chen et al., } 1997 \\
\text { [11] }\end{array}$ & Taiwan & 1 & $\mathrm{f}$ & Taiwan & $49 / 49$ & & mix-type & $+/+$ & $63 \mathrm{~g} / 1$ \\
\hline $\begin{array}{l}\text { Yoshida et al., } \\
1996 \text { [13] }\end{array}$ & Canada & 1 & $\mathrm{~m}$ & Indian & $66 / 66$ & PBC I & $\begin{array}{l}\mathrm{C}_{3}+\mathrm{IgG}+; \\
\text { warm-type }\end{array}$ & $+1-$ & $59 \mathrm{~g} / 1$ \\
\hline $\begin{array}{l}\text { Shichiri et al., } \\
1984 \text { [14] }\end{array}$ & Japan & 1 & $\mathrm{f}$ & Japanese & $32 / 32$ & $* * *$ & $\begin{array}{l}\mathrm{C}_{3}+\mathrm{IgG}+; \\
\text { warm-type }\end{array}$ & $+1-$ & $32 \mathrm{~g} / 1$ \\
\hline $\begin{array}{l}\text { Orlin et al., } 1980 \\
{[16]}\end{array}$ & USA & 1 & $\mathrm{f}$ & American & $51 / 57$ & $* * *$ & $\begin{array}{l}\mathrm{C}_{3}+; \\
\text { cold-type }\end{array}$ & $+1-$ & $23 \% * *$ \\
\hline $\begin{array}{l}\text { Hume et al., } 1970 \\
{[17]}\end{array}$ & England & 1 & $\mathrm{f}$ & English & $50 / 50$ & $* * *$ & $\begin{array}{l}+; \\
\text { warm-type }\end{array}$ & $+l^{*}$ & $68 \mathrm{~g} / 1$ \\
\hline
\end{tabular}

${ }^{*}$ Not performed or mentioned. ${ }^{* *}$ Hematocrit. ${ }^{* *}$ Compatible with PBC. ${ }^{\Delta}$ The second number was the age at liver transplantation 
Table 2. Treatment of PBC-related AIHA cases reported in the world literature

\begin{tabular}{|c|c|c|c|c|}
\hline Authors & $\begin{array}{l}\text { Initiated cortico- } \\
\text { steroid dosage }\end{array}$ & $\begin{array}{l}\text { Hb response to } \\
\text { corticosteroids }\end{array}$ & Other therapies to treat AIHA & Prognosis \\
\hline $\begin{array}{l}\text { Azad et al., } 2007 \\
{[4]}\end{array}$ & PSL 50 mg/day p.o. & very good* & AZA to maintain therapy & $\begin{array}{l}11 \text { months } \\
\text { follow-up } \\
\text { stable }\end{array}$ \\
\hline $\begin{array}{l}\text { Kaibori et al., } \\
2007[5]\end{array}$ & Did not use & & $\begin{array}{l}\text { immunosuppressant post } \\
\text { liver transplantation }\end{array}$ & $\begin{array}{l}1 \text { year } \\
\text { follow-up } \\
\text { stable }\end{array}$ \\
\hline \multirow[t]{2}{*}{$\begin{array}{l}\text { Retana et al., } \\
2007[6]\end{array}$} & $\begin{array}{l}\text { Methylprednisolone } \\
60 \text { mg/day i.v. }\end{array}$ & very good* & $\begin{array}{l}\text { rituximab and previous } \\
\text { immunosuppressant for liver } \\
\text { transplantation (taccrolimus } \\
\text { and UDCA) were used to } \\
\text { maintain therapy }\end{array}$ & $\begin{array}{l}4 \text { months } \\
\text { follow-up } \\
\text { stable }\end{array}$ \\
\hline & $\begin{array}{l}\text { methylprednisolone } \\
100 \mathrm{mg} / \text { day i.v. } \\
\text { did not use }\end{array}$ & $\begin{array}{l}\text { did not improve } \\
\text { for } 3 \text { days }\end{array}$ & $\begin{array}{l}\text { intravenous immunoglobulin } \\
\text { was administered, then the } \\
\text { patient improved }\end{array}$ & $\begin{array}{l}8 \text { months } \\
\text { follow-up } \\
\text { stable } \\
\text { died }\end{array}$ \\
\hline $\begin{array}{l}\text { Cantalapiedra et } \\
\text { al., } 2005 \text { [7] }\end{array}$ & $\begin{array}{l}\text { prednisone } \\
1 \mathrm{mg} / \mathrm{kg} \text { p.o. }\end{array}$ & very good ${ }^{*}$ & $\begin{array}{l}\text { UDCA } 15 \mathrm{mg} / \mathrm{kg} \text { was also } \\
\text { administered to the patient }\end{array}$ & \\
\hline $\begin{array}{l}\text { Fuller et al., } 2003 \\
{[8]}\end{array}$ & did not use & & $\begin{array}{l}\text { only UDCA was used; very } \\
\text { good response }\end{array}$ & $\begin{array}{l}1 \text { year } \\
\text { follow-up } \\
\text { stable }\end{array}$ \\
\hline $\begin{array}{l}\text { Nakasone et al., } \\
2000[9]\end{array}$ & PSL 60 mg/day p.o. & very good ${ }^{*}$ & $\begin{array}{l}\text { liver function was worsening } \\
\text { during the prednisolone } \\
\text { tapering phase, UDCA was } \\
\text { added to maintain therapy }\end{array}$ & $\begin{array}{l}1 \text { year } \\
\text { follow-up } \\
\text { stable }\end{array}$ \\
\hline $\begin{array}{l}\text { Brackstone and } \\
\text { Ghent, } 2000[10]\end{array}$ & $\begin{array}{l}\text { prednisone } \\
50 \mathrm{mg} / \text { day p.o. } \\
\text { prednisone } \\
20 \mathrm{mg} / \text { day p.o. }\end{array}$ & very good* & $\begin{array}{l}\text { at the same time, UDCA } \\
1 \mathrm{~g} / \text { day was also added to the } \\
\text { patient } \\
\text { AZA to maintain therapy }\end{array}$ & $\begin{array}{l}1 \text { year } \\
\text { follow-up } \\
\text { stable } \\
3 \text { years } \\
\text { follow-up } \\
\text { stable }\end{array}$ \\
\hline $\begin{array}{l}\text { Chen et al., } 1997 \\
\text { [11] }\end{array}$ & $\begin{array}{l}\text { methylprednisolone } \\
900 \text { mg/day i.v. }\end{array}$ & very good* & $\begin{array}{l}\text { at the corticosteroids tapering } \\
\text { phase, UDCA was added to } \\
\text { maintian therapy }\end{array}$ & $* *$ \\
\hline $\begin{array}{l}\text { Yoshida et al., } \\
1996[13]\end{array}$ & $\begin{array}{l}\text { prednisone } \\
125 \mathrm{mg} / \text { day p.o. } \\
(2 \mathrm{mg} / \mathrm{kg})\end{array}$ & very good* & & $\begin{array}{l}7 \text { months } \\
\text { follow-up } \\
\text { stable }\end{array}$ \\
\hline $\begin{array}{l}\text { Shichiri et al., } \\
1984 \text { [14] }\end{array}$ & $\begin{array}{l}\text { methylprednisolone } \\
1,326 \mathrm{mg} / \text { day i.v. }\end{array}$ & very good* & & $* * *$ \\
\hline $\begin{array}{l}\text { Orlin et al., } 1980 \\
\text { [16] }\end{array}$ & did not use & & plasma exchange & died \\
\hline $\begin{array}{l}\text { Hume et al., } 1970 \\
{[17]}\end{array}$ & $\begin{array}{l}\text { not mentioned in } \\
\text { the report }\end{array}$ & very good ${ }^{*}$ & & $* *$ \\
\hline
\end{tabular}

*Very good means hemolysis was controlled rapidly. ${ }^{*}$ Follow-up time not mentioned in the report, but the patient was discharged in good condition. ${ }^{* * *}$ Two months follow-up stable, then tiopronin was given and adverse reaction presented. 


\section{References}

1 Jones DE: Pathogenesis of primary biliary cirrhosis. Gut 2007;56:1615-1624.

2 Packman CH, Leddy JP: Aquired hemolytic anemia due to warm-reacting autoantibodies (chapter 64); in Bentler E, Lichtman MA, Coller BS, Kipps TJ (eds): Williams Hematology, ed 5. McGraw-Hill Health Professions Division, New York, 1995, pp 677-685.

-3 Gershwin ME, Selmi C, Worman HJ, Gold EB, Watnik M, Utts J, Lindor KD, Kaplan MM, Vierling JM: Risk factors and comorbidities in primary biliary cirrhosis: a controlled interview-based study of 1,032 patients. Hepatology 2005;42:1194-1202.

4 Azad A, Berera V, Jayarajan J, Lim K: Evans syndrome and primary biliary cirrhosis. Int J Lab Hematol 2007;29:145-148.

-5 Kaibori M, Uchida Y, Ishizaki M, Saito T, Hirohara J, Kishimoto Y, Uemura Y, Tanaka K, Kamivama Y: Living donor liver transplantion for primary biliary cirrhosis with autoimmune hemolytic anemia: a case report. Dig Dis Sci 2007;52:3237-3239.

-6 Retana AK, Kaplan MM, Erban JK: Autoimmune hemolytic anemia in patients with liver transplants for primary biliary cirrhosis: Three case reports and a review of the literature. Am J Gastroenterol 2007;102:197-200.

7 Cantalapiedra A, Penarrubia MJ, Gutierrez O, Garcia-Pajares F, Nunez H, Garcia-Frade J, Caro-Paton A: Primary biliary cirrhosis, 'sicca' syndrome and autoimmune hemolytic anemia. Rev Esp Enferm Dig 2005;97:678-679.

$>8$ Fuller SJ, Kumar P, Weltman M, Wiley JS: Autoimmune hemolysis associated with primary biliary cirrhosis responding to ursodeoxycholic acid as sole treatment. Am J Hematol 2003;72:31-33.

-9 Nakasone H, Sakugawa H, Fukuchi J, Miyagi T, Sugama R, Hokama A, Nakayoshi T, Kawakami Y, Yamashiro T, Kinjo F, Saito A, Taira N, Toda T, Kan I: A patient with primary biliary cirrhosis associated with autoimmune hemolytic anemia. J Gastroenterol 2000;35:245-249.

-10 Brackstone M, Ghent CN: Primary biliary cirrhosis and hemolytic anemia confusing serum bilirubin levels. Can J Gastroenterol 2000;14:445-447.

$\checkmark 11$ Chen CY, Lu CL, Chiu CF, Lee SD: Primary biliary cirrhosis associated with mixed type autoimmune hemolytic anemia and sicca syndrome: a case report and review of literature. Am J Gastroenterol 1997;92:1547-1549.

-12 Kobayashi N, Ohta M, Kondo M, Sakai M, Mori T, Fujino H, Oishi T, Inada Y, Kanemasa H, Yasuda H, Okanoue T, Kashima K: A case report of primary biliary cirrhosis with autoimmune hemolytic anemia. Nippon Shokakibyo Gakkai Zasshi 1997;94:552-557.

-13 Yoshida EM, Nantel SH, Owen DA, Galbraith PF, Dalal BI, Ballon HS, Kwan SY, Wade JP, Erb SR: Case report: a patient with primary biliary cirrhosis and autoimmune hemolytic anemia. J Gastroenterol Hepatol 1996;11:439-442.

14 Shichiri M, Koyama W, Tozuka S, Sakamoto S, Kanayama M: Primary biliary cirrhosis. A patient with adverse reactions to tiopronin and autoimmune hemolytic anemia with reticulocytopenia. Arch Intern Med 1984;144:89-91.

$\checkmark 15$ Wolf HW: Autoimmune myocarditis, hemolytic anemia and primary biliary cirrhosis (in German). Dtsch Med Wochenschr 1982,107:77.

16 Orlin JB, Berkman EM, Matloff DS, Kaplan MM: Primary biliary cirrhosis and cold autoimmune hemolytic anemia: effect of partial plasma exchange. Gastroenterology 1980;78:576-578.

17 Hume R, Williamson JM, Whitelaw JW: Red cell survival in biliary cirrhosis. J Clin Pathol 1970;23:397-401.

18 Kaplan MM, Gershwin ME: Primary biliary cirrhosis. N Engl J Med 2005;353:1261-1273.

19 Lazaridis KN, Talwalkar JA: Clinical epidemiology of primary biliary cirrhosis: incidence, prevalence, and impact of therapy. J Clin Gastroenterol 2007;41:494500.

20 Rautiainen H, Karkkainen P, Karvonen AL, Nurmi H, Pikkarainen P, Nuutinen H, Farkkila M: Budesonide combined with UDCA to improve liver histology in primary biliary cirrhosis: a three-year randomized trial. Hepatology 2005;41:747752. 
21 Prince MI, Chetwynd A, Craig WL, Metcalf JV, James OF: Asymptomatic primary biliary cirrhosis: clinical features, prognosis, and symptom progression in a large population based cohort. Gut 2004;53:865-870. 